\title{
Pengaruh Brand Awareness dan Customer Experience Terhadap Customer Loyalty Pada Sate Cak Ahmad (Survey Konsumen Cak Ahmad di Kota Bandung)
}

\author{
Delia Dewi Anjani*, Ratih Tresnati \\ Prodi Manejemen Bisnis, Fakultas Ekonomi dan Bisnis, Universitas Islam \\ Bandung, Indonesia.
}

deliadewiaa@gmail.com, ratihtresnati27@gmail.com

\begin{abstract}
The purpose of this study was to determine the implementation of Brand Awareness at Sate Cak Ahmad, to determine the implementation of Customer Experience at Sate Cak Ahmad, to determine the implementation of Customer Loyalty at Sate Cak Ahmad, and to find out how much influence the Brand Awareness and Customer Experience on Customer Loyalty at Sate Cak Ahmad. . The method used is a survey method with a sampling technique using a non-probability sampling technique, and the type of non-probability sampling technique selected is an incidental technique. This type of research is verification with a quantitative approach. The population in this study were customers of Sate Cak Ahmad in the city of Bandung. The sample taken were 100 respondents. The data analysis method used is multiple linear regression analysis which aims to determine the direction of the relationship between the independent variables, namely Brand Awareness (X1) and Customer Experience (X2) with the dependent variable, namely Customer Loyalty (Y). The results of this test state that the Brand Awareness variable partially has a significant effect on Customer Loyalty, and simultaneously the Brand Awareness and Customer Experience variables have a significant effect on Customer Loyalty at Sate Cak Ahmad.
\end{abstract}

Keywords: Brand Awareness, Customer Experience, Customer Loyalty

Abstrak. Penelitian ini bertujuan untuk mengetahui implementasi Brand Awareness pada Sate Cak Ahmad, untuk mengetahui implementasi Customer Experience pada Sate Cak Ahmad, untuk mengetahui implementasi Customer Loyalty pada Sate Cak Ahmad, dan untuk mengetahui seberapa besar pengaruh Brand Awareness dan Customer Experience terhadap Customer Loyalty pada Sate Cak Ahmad. Metode yang digunakan adalah metode survey dengan teknik pengambilan sampel menggunakan teknik non-probability sampling, dan jenis teknik non-probability sampling yang dipilih ialah teknik insidential. Jenis penelitian ini adalah verifikatif dengan pendekatan kuantitatif. Populasi dalam penelitian ini adalah pelanggan Sate Cak Ahmad di Kota Bandung. Sampel yang diambil adalah 100 orang responden. Metode analisis data yang digunakan adalah analisis regresi linier berganda yang bertujuan untuk mengetahui arah hubungan antara variabel independen yaitu Brand Awareness (X1) dan Customer Experience (X2) dengan variabel dependen yaitu Customer Loyalty (Y). Hasil pengujian ini menyatakan bahwa variabel Brand Awareness secara parsial berpengaruh signifikan terhadap Customer Loyalty, dan secara simultan variabel Brand Awareness dan Customer Experience berpengaruh signifikan terhadap Customer Loyalty pada Sate Cak Ahmad.

Kata Kunci: Brand Awareness, Customer Experience, Customer Loyalty 


\section{A. Pendahuluan}

Pada era globalisasi saat ini, perdagangan dapat dilakukan secara global. Tidak terdapat lagi batasan bagi setiap pengusaha untuk memasarkan dan menjual produk usahanya. Untuk dapat tumbuh pada pasar global, maka setiap perusahaan dituntut untuk dapat membangun sistem manajemen yang profesional dalam meretensi para konsumennya. Hal itu menyebabkan diperlukan adanya upaya-upaya yang kreatif dan inovatif dalam membangun sistem manajemen, khususnya dalam hal pengembangan produk. Industri dibidang kuliner merupakan salah satu jenis industri yang sedang berkembang pesat saat ini khususnya di Indonesia. Hal ini disebabkan karena adanya daya jual dan tingkat permintaan yang tinggi dari konsumen, sehingga dapat menyebabkan tingginya karakteristik konsumen dalam memilih tempat makan dan jenis kuliner yang akan dibeli. Beragamnya karakteristik konsumen dan perbedaan selera konsumsi masyarakat di Indonesia menuntut para pengusaha kuliner agar dapat beradaptasi melalui perubahan strategi dan konsep usaha, sehingga mampu bersaing di pasaran dengan baik.

Kota Bandung merupakan salah satu kota di Indonesia yang menjadi sasaran dan alternatif masyarakat dalam berwisata. Kota Bandung juga dijuluki Paris Van Java, karena di kota ini terdapat banyak wisata kuliner, wisata belanja, dan wisata alam (Swantoro, 2016). Banyaknya jumlah usaha tempat makan atau kuliner di Kota Bandung menyebabkan persaingan dalam pasar kuliner semakin ketat. Terdapat berbagai jenis produk makanan yang terkenal di Kota Bandung, baik makanan tradisional maupun makanan modern. Salah satu kuliner yang legendaris di Kota Bandung adalah kuliner sate. Sate termasuk salah satu kuliner Indonesia yang banyak disukai oleh masyarakat kota Bandung.

Sate asin pedas merupakan salah satu jenis kuliner yang terkenal di Kota Bandung (Pingpoint.co.id). Jika Jakarta memiliki sate taichan, maka Kota Bandung memiliki sate asin pedas. Sate asin pedas memiliki ciri khas rasa "asin pedas" yang sesuai dengan cita rasa budaya Sunda, salah satunya di Kota Bandung. Sate asin pedas sudah menjadi kuliner terkenal di Kota Bandung yang memiliki ciri khas rasa asin pedas. Para wisatawan kuliner dapat menemukan sate asin pedas di berbagai Kota Bandung. Salah satunya adalah Sate Cak Ahmad. Sate Asin Pedas Cak Ahmad memiliki rasa khas "asin pedas" dengan harga jual Rp 15.000 - Rp 20.000, terletak di Jalan Ambon No. 9, Lapangan Saparua, Riau, Kota Bandung. Kuliner Sate Cak Ahmad memang tidak memiliki tempat permanen seperti gedung bangunan atau ruang yang terbuat dari tembok permanen seperti beberapa pedagang sate lainnya. Sate Cak Ahmad termasuk jenis kuliner golongan pedagang kaki lima yang menjadikan lapangan Saparua sebagai lokasi tetap.

Berdasarkan permasalahan di atas, penelitian ini memiliki tujuan untuk memperoleh temuan mengenai:

1. Untuk mengetahui gambaran brand awareness pada Sate Cak Ahmad.

2. Untuk mengetahui gambaran customer experience pada Sate Cak Ahmad.

3. Untuk mengetahui gambaran customer loyalty pada Sate Cak Ahmad.

4. Untuk mengetahui seberapa besar pengaruh brand awareness terhadap customer loyalty pada Sate Cak Ahmad.

5. Untuk mengetahui seberapa besar pengaruh customer experience terhadap customer loyalty pada Sate Cak Ahmad.

6. Untuk mengetahui seberapa besar pengaruh brand awareness dan customer experience terhadap customer loyalty pada Sate Cak Ahmad.

\section{B. Metodologi Penelitian}

Metode penelitian yang digunakan didalam penelitian ini adalah metode penelitian survey. Jenis penelitian ini adalah deskriptif dan verifikatif dengan pendekatan kuantitatif. Populasi dalam penelitian ini adalah masyarakat di Kota Bandung yang membeli produk dari Sate Cak Ahmad di Saparua Kota Bandung. Teknik sampling yang digunakan dalam penelitian ini ialah teknik non-probability sampling, dan jenis teknik non-probability sampling yang dipilih ialah sampling insidential. Sampel yang digunakan dalam penelitian ini berjumlah 100 orang. Instrumen penelitian yang digunakan dalam penelitian ini adalah pedoman kuesioner dan wawancara. Serta 
metode data yang digunakan adalah analisis regresi linier berganda. Dalam penelitian ini menggunakan variabel independen Brand Awareness dan Customer Experience, serta variabel dependen Customer Loyalty.

\section{Brand Awareness}

Kotler dan Keller (2017) mendeskripsikan brand awareness adalah kemampuan konsumen untuk menelaah suatu merek pada situasi yang berbeda dan tercermin dalam brand recognition. Menurut Keller dalam Hermawan (2012) terdapat empat indikator brand awareness (kesadaran merek) yaitu:

1. Recall (ingatan kembali), yaitu tindakan mengingat kembali ketika ditanyai merek produk apa saja yang ada di dalam benak konsumen.

2. Recognition (pengenalan), yaitu kemampuan konsumen untuk mengenali merek dalam satu kategori tertentu. Sehingga perusahaan dapat meningkatkan hal ini dengan membuat nama merek yang berbeda, khusus, dan tidak umum.

3. Purchase (pembelian), yaitu suatu keputusan konsumen dalam memasukkan merek menjadi alternatif pilihan ketika akan membeli barang atau jasa.

4. Consumption (konsumsi), yaitu pengukuran ingatan (memori) konsumen pada suatu merek ketika mereka menggunakan produk pesaing, sehingga perusahaan harus mampu memberikan ingatan (memori) kuat kepada konsumen mengenai mereknya.

\section{Customer Experience}

Menurut Buchari Alma (2016) customer experience (pengalaman pelanggan) adalah pengalaman yang didapatkan secara mengesankan dan tidak terlupakan, pengalaman positif, dan pengalaman holistic melalui seluruh panca inderanya. Menurut Schmitt dalam Dewi \& Hasibuan (2019) terdapat beberapa indikator dari customer experience (pengalaman pelanggan) yaitu sebagai berikut:

1. Sense (rasa), menyangkut kelima panca indera manusia yang dapat dirasakan melalui penglihatan, pendengaran, perabaan, pengecapan, dan atau penciuman yang sesuai dengan keinginan dan harapan konsumen.

2. Feel (perasaan), yaitu emosi atau perasaan positif yang dirasakan konsumen ketika mengkonsumsi suatu produk.

3. Think (berpikir), kemampuan konsumen dalam berpikir kreatif dan menilai kembali suatu barang atau jasa yang telah dikonsumsi.

4. Act (bertindak), mengenai perubahan atau tingkah laku secara fisik yang mengakibatkan konsumen berperilaku lebih aktif terkait dengan produk tersebut.

5. Relate (berhubungan), yaitu upaya untuk menghubungkan suatu produk atau merek dengan kepribadian konsumen, budaya, atau lingkungannya.

\section{Customer Loyalty}

Kotler dan Keller (2016) mendefinisikan loyalitas pelanggan sebagai suatu komitmen pelanggan dalam membeli atau mendukung kmbali suatu barang atau jasa yang digunakan di masa yang akan datang, meskipun terdapat situasi dan kondisi pemasaran yang dapat berpotensi pelanggan akan beralih. Kotler \& Keller (2016) mengemukakan terdapat tiga indikator customer loyalty (loyalitas pelanggan), yaitu:

1. Repeat purchase (pembelian ulang)

Perilaku pembelian berulang (lebih dari satu kali) yang dilakukan pelanggan terhadap suatu produk atau jasa sebagai bentuk kesetiaan.

2. Retention (ketahanan)

Pelanggan akan tetap berpikir positif dan kebal terhadap pengaruh negatif mengenai produk atau jasa suatu perusahaan serta tidak mudah berpindah ke produk maupun jasa yang lain (kompetitor).

3. Refers other (mereferensikan atau merekomendasikan kepada orang lain) Pelanggan akan memberikan informasi positif dan mereferensikan atau merekomendasikan kepada orang lain mengenai produk atau jasa yang sudah ia percaya sehingga orang lain ikut membeli produk atau jasa tersebut. 


\section{Hasil Penelitian dan Pembahasan}

\section{Garis Kontinum Variabel Brand Awareness (X1)}

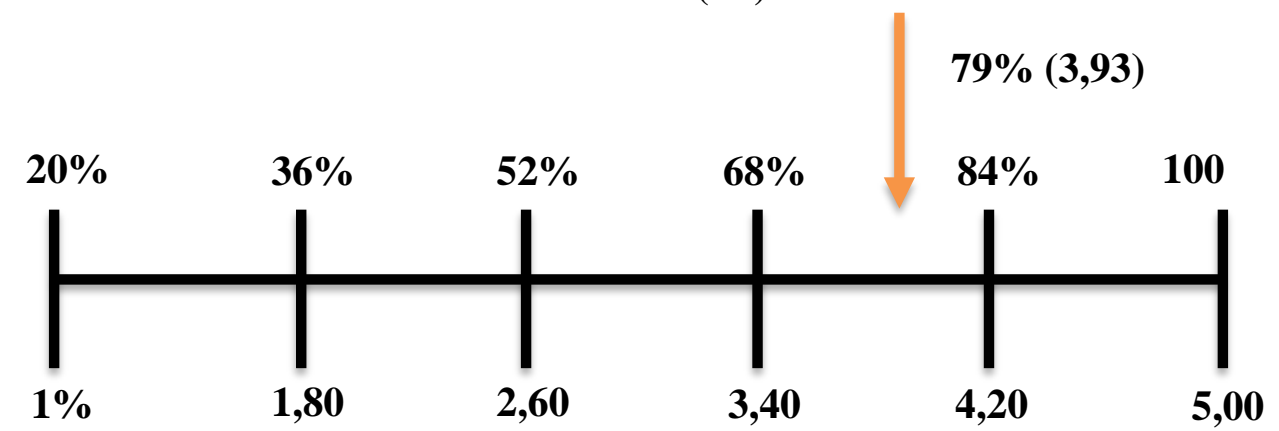

Gambar 1. Garis Kontinum Variabel Brand Awareness

Sumber: Data diolah penulis (2021)

Kesimpulan yang dapat ditarik berdasarkan garis kontinum diatas, bahwa tanggapan responden mengenai variabel Brand Awareness (X1) menghasilkan rata-rata skor dari seluruh indikator variabel Brand Awareness sebesar 3,93 (79\%), dimana dengan nilai tersebut termasuk ke dalam kategori Baik. Artinya secara keseluruhan dapat disimpulkan bahwa pelanggan Sate Cak Ahmad merasakan Brand Awareness (kesadaran merek) yang Baik.

\section{Garis Kontinum Variabel Customer Experience (X2)}

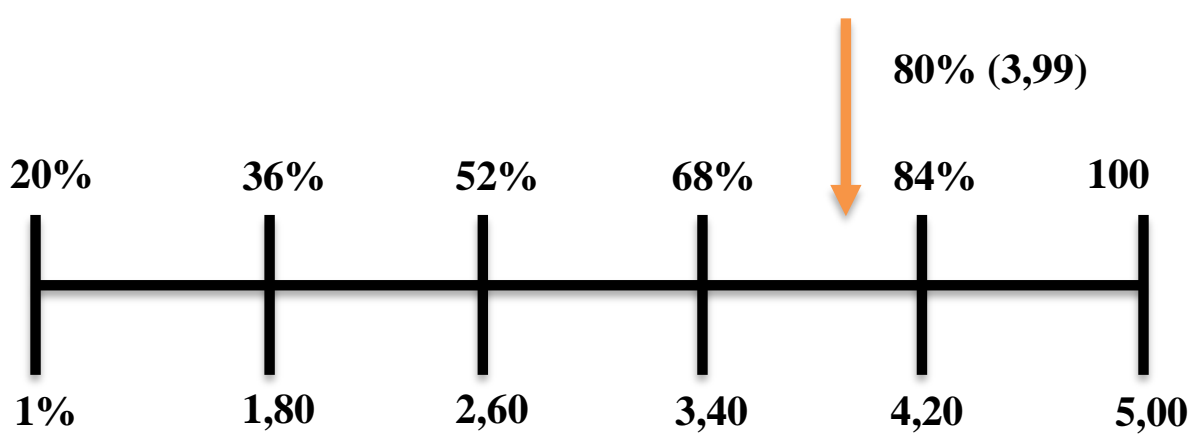

Gambar 2. Garis Kontinum Variabel Customer Experience

Sumber: Data diolah penulis (2021)

Kesimpulan yang dapat ditarik berdasarkan garis kontinum diatas, bahwa tanggapan responden mengenai variabel Customer Experience (X2) menghasilkan rata-rata skor dari seluruh indikator variabel Customer Experience sebesar 399 (80\%), dimana dengan nilai tersebut termasuk ke dalam kategori Baik. Artinya secara keseluruhan dapat disimpulkan bahwa pelanggan Sate Cak Ahmad merasakan Customer Experience (pengalaman pelanggan) yang Baik. 
Garis Kontinum Variabel Customer Loyalty (Y)

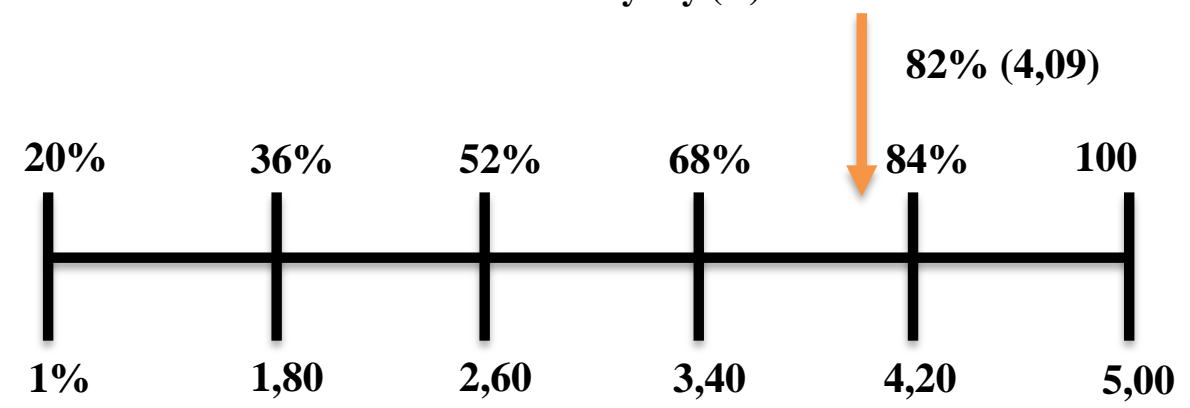

Gambar 3. Garis Kontinum Variabel Customer Loyalty

Sumber: Data diolah penulis (2021)

Kesimpulan yang dapat ditarik berdasarkan garis kontinum diatas, bahwa tanggapan responden mengenai variabel Customer Loyalty (Y) menghasilkan rata-rata skor dari seluruh indikator variabel Customer Loyalty sebesar 409 (82\%), dimana dengan nilai tersebut termasuk ke dalam kategori Baik. Artinya secara keseluruhan dapat disimpulkan bahwa pelanggan Sate Cak Ahmad melakukan Customer Loyalty (loyalitas pelanggan) yang Baik.

\section{Hasil Uji Validitas dan Reliabilitas}

Tabel 1. Hasil Uji Validitas Variabel Brand Awareness (X1), Customer Experience (X2), dan Customer Loyalty (Y)

\begin{tabular}{|l|c|c|c|}
\hline Pertanyaan & $\boldsymbol{r}_{\text {hitung }}$ & $\boldsymbol{r}_{\text {tabel }}$ & Keterangan \\
\hline X1.1 & 0,757 & 0,361 & Valid \\
\hline X1.2 & 0,729 & 0,361 & Valid \\
\hline X 1.3 & 0,644 & 0,361 & Valid \\
\hline X1.4 & 0,832 & 0,361 & Valid \\
\hline X1.5 & 0,716 & 0,361 & Valid \\
\hline X1.6 & 0,747 & 0,361 & Valid \\
\hline X1.7 & 0,695 & 0,361 & Valid \\
\hline X2.1 & 0,588 & 0,361 & Valid \\
\hline X2.2 & 0,677 & 0,361 & Valid \\
\hline X2.3 & 0,773 & 0,361 & Valid \\
\hline X2.4 & 0,840 & 0,361 & Valid \\
\hline X2.5 & 0,859 & 0,361 & Valid \\
\hline X2.6 & 0,641 & 0,361 & Valid \\
\hline X2.7 & 0,761 & 0,361 & Valid \\
\hline X2.8 & 0,809 & 0,361 & Valid \\
\hline X2.9 & 0,462 & 0,361 & Valid \\
\hline X2.10 & 0,762 & 0,361 & Valid \\
\hline Y.1 & 0,708 & 0,361 & Valid \\
\hline Y.2 & 0,705 & 0,361 & Valid \\
\hline Y.3 & 0,732 & 0,361 & Valid \\
\hline Y.4 & 0,669 & 0,361 & Valid \\
\hline Y.5 & 0,814 & 0,361 & Valid \\
\hline & 0,728 & 0,361 & Valid \\
\hline
\end{tabular}

Sumber: Data diolah penulis di SPSS 25 (2021)

Pada tingkat signifikansi 5\% terlihat bahwa 8 pertanyaan variabel Brand Awareness (X1), 10 pertanyaan variabel Customer Experience (X2), dan 5 pertanyaan variabel Customer Loyalty (Y) memiliki nilai lebih besar dari $\mathrm{r}$ tabel dan semua pertanyaan tersebut bertanda positif, sehingga semua pertanyaan dinyatakan valid. 
Tabel 2. Hasil Uji Reliabilitas

\begin{tabular}{|l|l|l|}
\hline Variabel & Cronbach Alpha & Keterangan \\
\hline Brand Awareness & 0,911 & Reliabel, Sangat Tinggi \\
\hline Customer Experience & 0,928 & Reliabel, Sangat Tinggi \\
\hline Customer Loyalty & 0,884 & Reliabel, Sangat Tinggi \\
\hline
\end{tabular}

Sumber: Data Kuesioner yang diolah oleh penulis (2021)

Berdasarkan hasil uji reliabilitas pada tabel diatas, variabel brand awareness memiliki nilai cronbach alpha sebesar 0,911>0,60, variabel customer experience (X2) memiliki nilai cronbach alpha sebesar 0,928 >0,60, dan variabel customer loyalty (Y) memiliki nilai cronbach alpha sebesar 0,884 > 0,60 yang memiliki arti masing-masing bersifat reliabel dengan tingkat reliabilitas sangat tinggi.

\section{Analisis Regresi Linier Berganda}

Teknik analisis data yang digunakan dalam penelitian ini adalah analisis regresi linier berganda, dengan tujuan untuk memperoleh gambaran yang menyeluruh mengenai hubungan antara variabel satu dengan variabel yang lain.

Tabel 3. Persamaan Regresi Liner Berganda

\begin{tabular}{|c|c|c|c|c|c|c|c|c|}
\hline \multicolumn{9}{|c|}{ Coefficients $^{a}$} \\
\hline \multirow{2}{*}{\multicolumn{2}{|c|}{ Model }} & \multicolumn{2}{|c|}{$\begin{array}{l}\text { Unstandardized } \\
\text { Coefficients }\end{array}$} & \multirow{2}{*}{$\begin{array}{l}\text { Standardized } \\
\text { Coefficients } \\
\text { Beta }\end{array}$} & \multirow[t]{2}{*}{$\mathrm{t}$} & \multirow[t]{2}{*}{ Sig. } & \multicolumn{2}{|c|}{ Collinearity Statistics } \\
\hline & & B & Std. Error & & & & Tolerance & VIF \\
\hline \multirow[t]{3}{*}{1} & (Constant) & .362 & 1.630 & & .222 & .825 & & \\
\hline & $\begin{array}{l}\text { Brand } \\
\text { Awareness } \\
\text { (X1) }\end{array}$ & .336 & .073 & .470 & 4.622 & .000 & .347 & 2.879 \\
\hline & $\begin{array}{l}\text { Customer } \\
\text { Experience } \\
\text { (X2) }\end{array}$ & .221 & .059 & .379 & 3.731 & .000 & .347 & 2.879 \\
\hline
\end{tabular}

a. Dependent Variable: Customer Loyalty

Sumber: Data diolah di SPSS 25 (2021)

Dari hasil pengolahan data diatas diketahui nilai konstanta dan koefisien regresi sehingga dapat dibentuk persamaan regresi linier berganda sebagai berikut: $Y=0,362+$ $0,336 X_{1}+0,221 X_{2}$

\section{Koefisien Determinasi $\left(R^{2}\right)$}

Bertujuan untuk mencari besarnya peranan variabel Brand Awareness dan Customer Experience terhadap Customer Loyalty.

Tabel 4. Pengaruh Brand Awareness dan Customer Experience terhadap Customer Loyalty

\begin{tabular}{|l|l|l|l|l|}
\hline \multicolumn{4}{|l|}{ Model Summary } \\
\hline Model & $\mathrm{R}$ & R Square & $\begin{array}{l}\text { Adjusted } \\
\text { Square }\end{array}$ & $\begin{array}{l}\text { Std. Error of } \\
\text { the Estimate }\end{array}$ \\
\hline 1 & $.807^{\mathrm{a}}$ & .652 & .645 & 2.271558 \\
\hline $\begin{array}{l}\text { a. Predictors: (Constant), Customer } \\
\text { Awareness }\end{array}$ \\
\hline
\end{tabular}

Sumber: data diolah di SPSS 25 (2021)

Hasil R Square $=0,652$ atau $65,2 \%$ yang diperoleh, artinya Customer Loyalty dipengaruhi oleh variabel Brand Awareness dan Customer Experience sebesar 65,2\% sedangkan sisanya $34,8 \%$ dipengaruhi oleh faktor dan variabel lainnya yang tidak diteliti peneliti saat ini. 


\section{Hasil Uji Hipotesis}

\section{Uji Parsial (Uji-t)}

Uji parsial (uji-t) digunakan untuk menguji pengaruh masing-masing variabel bebas (Brand Awareness dan Customer Experience) terhadap variabel terikat (Customer Loyalty) dengan rumusan hipotesis statistik sebagai berikut:

1. $H_{o}: \beta_{1}=0$, variabel tidak memiliki pengaruh secara signifikan pada Customer Loyalty.

2. $H_{a}: \beta_{1} \neq 0$, variabel memiliki pengaruh secara signifikan pada Customer Loyalty.

Tabel 5. Pengujian Hipotesis Uji-t Pengaruh Brand Awareness dan Customer Experience Terhadap Customer Loyalty pada Sate Cak Ahmad

\begin{tabular}{|c|c|c|c|c|c|c|}
\hline \multicolumn{7}{|c|}{ Coefficients $^{\mathrm{a}}$} \\
\hline \multirow{2}{*}{\multicolumn{2}{|c|}{ Model }} & \multicolumn{2}{|c|}{$\begin{array}{l}\text { Unstandardized } \\
\text { Coefficients }\end{array}$} & $\begin{array}{l}\text { Standardized } \\
\text { Coefficients }\end{array}$ & \multirow[t]{2}{*}{$\mathrm{t}$} & \multirow[t]{2}{*}{ Sig. } \\
\hline & & \multirow{2}{*}{$\begin{array}{l}\text { B } \\
.362 \\
\end{array}$} & \multirow{2}{*}{$\begin{array}{l}\text { Std. } \\
\text { Error } \\
1.630\end{array}$} & Beta & & \\
\hline \multirow[t]{3}{*}{1} & (Constant) & & & & .222 & .825 \\
\hline & $\begin{array}{l}\text { Brand } \\
\text { Awareness (X1) }\end{array}$ & .336 & .073 & .470 & 4.622 & .000 \\
\hline & $\begin{array}{l}\text { Customer } \\
\text { Experience (X2) }\end{array}$ & .221 & .059 & .379 & 3.731 & .000 \\
\hline
\end{tabular}

Sumber: Data diolah di SPSS 25 (2021)

Dapat diketahui bahwa nilai uji-t variabel Brand Awareness didapatkan hasil sebesar 4,622 > 1,984 dengan probabilitas $0,000<0,05$ maka dari itu $H_{o}$ ditolak dan $H_{a}$ diterima, yang artinya terdapat pengaruh yang signifikan antara Brand Awareness terhadap Customer Loyalty pada Sate Cak Ahmad. Sedangkan dapat diketahui bahwa nilai uji-t variabel Customer Experiece didapatkan hasil sebesar 3,731 > 1,984 dengan probabilitas $0,000<0,05$ maka dari itu $H_{o}$ ditolak dan $H_{a}$ diterima, yang artinya terdapat pengaruh yang signifikan antara Customer Experience terhadap Customer Loyalty pada Sate Cak Ahmad.

\section{Uji Simultan (Uji-F)}

Uji simultan (uji-f) digunakan untuk mengetahui pengaruh seluruh variabel Brand Awareness dan Customer Experience secara simultan berperan signifikan pada variabel Customer Loyalty, dengan rumusan hipotesis sebagai berikut:

1. $H_{o}: \beta_{1}=0$, variabel Brand Awareness (X1) dan Customer Experience (X2) secara simultan tidak berperan signifikan terhadap variabel Customer Loyalty (Y) pada Sate Cak Ahmad.

2. $H_{a}: \beta_{1} \neq 0$, variabel Brand Awareness (X1) dan Customer Experience (X2) secara simultan berperan signifikan terhadap variabel Customer Loyalty (Y) pada Sate Cak Ahmad.

Tabel 6. Pengujian Hipotesis Uji-F

\begin{tabular}{|c|c|c|c|c|c|c|}
\hline \multicolumn{7}{|c|}{ ANOVA $^{\mathbf{a}}$} \\
\hline \multicolumn{2}{|c|}{ Model } & $\begin{array}{ll}\text { Sum } & \text { of } \\
\text { Squares } & \end{array}$ & df & Mean Square & $\mathrm{F}$ & Sig. \\
\hline \multirow[t]{3}{*}{1} & Regression & 937.829 & 2 & 468.914 & 90.875 & $.000^{\mathrm{b}}$ \\
\hline & Residual & 500.518 & 97 & 5.160 & & \\
\hline & Total & 1438.347 & 99 & & & \\
\hline \multicolumn{7}{|c|}{ a. Dependent Variable: Customer Loyalty } \\
\hline \multicolumn{7}{|c|}{ b. Predictors: (Constant), Customer Experience, Brand Awareness } \\
\hline
\end{tabular}


$F_{\text {hitung }}>F_{\text {tabel }}$ dikarenakan 90,875 > 3,94. Maka pada tingkat kekeliruan 5\% $(\alpha-0,05)$ diputuskan untuk menolak $H_{o}$ dan menerima $H_{a}$. Sehingga dapat disimpulkan dengan tingkat kepercayaan 95\% bahwa Brand Awareness dan Customer Experience secara simultan berpengaruh signifikan pada variabel Customer Loyalty.

\section{Kesimpulan}

Berdasarkan hasil penelitian mengenai "Pengaruh Brand Awareness dan Customer Experience Terhadap Customer Loyalty pada Sate Cak Ahmad" maka peneliti menarik beberapa kesimpulan:

1. Tingkat Brand Awareness pada Sate Cak Ahmad memiliki rata-rata 3,93 atau bernilai $79 \%$, nilai tersebut memberikan gambaran bahwa pelanggan memiliki tingkat kesadaran merek yang baik.

2. Tingkat Customer Experience pada Sate Cak Ahmad memiliki rata-rata 3,99 atau bernilai $80 \%$, nilai tersebut memberikan gambaran bahwa pelanggan memiliki tingkat pengalaman yang baik.

3. Tingkat Customer Loyalty pada Sate Cak Ahmad memiliki rata-rata 4,09 atau bernilai $82 \%$, nilai tersebut memberikan gambaran bahwa pelanggan memiliki tingkat loyalitas yang baik.

4. Secara parsial terdapat pengaruh yang signifikan antara Brand Awareness dengan Customer Loyalty pada sate Cak Ahmad.

5. Secara parsial terdapat pengaruh yang signifikan antara Customer Experience dengan Customer Loyalty pada sate Cak Ahmad.

6. Secara simultan variabel Brand Awareness dan variabel Customer Experience berpengaruh signifikan terhadap variabel Customer Loyalty pada Sate Cak Ahmad.

\section{Daftar Pustaka}

[1] Alma, Buchari. 2016. Manajemen Pemasaran dan Pemasaran Jasa. Bandung: Alfabeta.

[2] Dewi, Ira Triyana \& Muhammad Irwansyah Hasibuan. 2019. Pengaruh Pengalaman Pelanggan (Customer Experience) Terhadap Kepuasan Pelanggan pada Rumah Makan Kuliner Jawa Rantau Prapat. Jurnal Ecobisma, 3(1), H. 93103. https://doi.org/10.36987/ecobi.v3il.695

[3] Hermawan, Agus. 2012. Komunikasi Pemasaran. Jakarta: Erlangga.

[4] Kotler, Philip \& Amstrong. 2017. Manajemen Pemasaran, Jilid 1, Edisi 13. Jakarta: Erlangga.

[5] Kotler, Philip \& Keller, kevin Lane. 2016. Marketing Management 15th Edition. England: Pearson. 